\title{
The Effectiveness of Natural Approach on Language Learning in Higher Education
}

\author{
Mohammad Amiruddin ${ }^{1 .},{ }^{*}$ Ukhti Raudhatul Jannah ${ }^{2}$
}

\author{
${ }^{1}$ English Department, Madura University, Pamekasan Indonesia \\ ${ }^{2}$ Mathematics Department, Madura University, Pamekasan Indonesia \\ ${ }^{*}$ Corresponding author. Email: amiruddin@unira.ac.id
}

\begin{abstract}
This study aims to describe the effectiveness of the natural approach in language learning in higher education. This study is an experimental research using a quantitative approach. A sample is decided using a random sampling technique. The subjects of this study are 36 students of A-class as the control group with a conventional approach, grammar-translation, and 36 students of B class as the experimental group. The data are analyzed by the t-test technique. The result of the study shows sig (p) is significant. It is smaller than 0.05 (it is 0.028). The difference can be considered true. The mean difference is -6.36 . 49.25 are the mean in the pretest, and the mean of the posttest is 58.52. It shows that the students at higher education with a natural approach have better English proficiency levels than those who are not. It is more effective than conventional approaches, methods, etc in increasing English language proficiency level at higher education. The natural approach can be implemented in English language learning in higher education. It enriches the students' input to talk in English, besides, decreases their hesitation in English language learning. It implies that the teachers and members of academic society should help students with natural communication to offer meaningful input.
\end{abstract}

Keywords: Effectiveness, natural approach, Language, Learning, Higher Education.

\section{INTRODUCTION}

English is the dominant language studied by students in Indonesia in particular Madura. They are many students who study English to prepare themselves for a millennial period. English is used in business, commerce, education, etc. English will be easy to be learning if teachers provide appropriate approaches in their language learning. Approaches are the philosophies of teachers about language teaching that can be applied in the classrooms by using different techniques of language teaching.

Students are motivated to study English when they are at a low anxiety level and hesitant. It is difficult for the students when the teachers force them to produce words or phrases in English before they are ready. Besides, discussing grammar rules is also another factor influencing the students' anxiety in language learning. It provides an uncomfortable language environment for the students. The teachers should give opportunities to the students to interact freely with the teacher and other learners [1] and [2]. It $\mathrm{t}$ is essential for the teachers to consider the students' cognitive level in designing the class and inviting students to have interaction. It should come and flow naturally [3].

The natural approach gives students no forced to utter words, phrases, clauses, or sentences. It much less utters them correctly. It also does not drills correct usage and grammar rules as well as not cover a long list of vocabularies on the students' heads [4]. Students will have no worry, no hurry, and no anxiety to produce English. This situation helps the students to have a spontaneous speech since it gives them meaningful and memorable input [5]. The natural approach seats a lesser amount of importance on teacher monologues, direct repetition, formal questions and answers, and a smaller amount of meeting points on correct production of target language sentences. It has a center of attention on exposure or input rather than put into practice; optimizing touching attentiveness for learning; an expanded phase of concentration to what the language learners hear before they attempt to make language; and a will-ingness to use written and other materials as a source of comprehensible input [6].

Its importance is on presenting comprehensible input in the target language. The teachers are talking focuses on the substance in the classroom and on the content of pictures. It is important for the teachers to allow the students to speak English when they are ready to minimize stress; however, they are estimated to take action to teacher instructions and questions in other behavior [7]. When learners are ready to start conversations in the 
new language, the teachers provide understandable language and easy response oppor-tunities. The teachers talk slowly and clearly. The teachers facilitate a regular progression from Yes/ No questions, through either-or questions, to questions that students can rejoin using expressions they have heard used by the teachers. The students are not projected to use utterances enthusiastically until they have experiences in many times. The teachers are possible to use charts, pictures, advertisements, and other media to give questions to the students. The focus of the class is meaningful interaction rather than linguistics forms. Learning the language is usually understood involving the development of implicit knowledge of the language. It normally comes from interaction.

Nowadays, the students in higher education need to have the capability to communicate and to deliver meaning with others in English without too much focus on linguistics forms. Interactions in English, as well as much focus on the forms, are the students' problems in higher education. They have difficulties joining exchange in English. They are in high worry to speak English since their anxiety is at a high level when the teachers strengthen them to talk English. Also, they are distress about construction and errors in producing English. It causes a distance to the teachers. The conventional approach applied by the teachers in higher education is emphasizing the rules and the exercises emphasize the conscious control of the structure. When the teachers and the students have closeness, it helps the students to have and boost the motivation as well as decline they're hesitant to speak English [8]. It helps the students in particular beginner students to understand easily the explanation and the content of material of a subject. Also, it makes the students more strongly to the environment and to have nice interaction between the teachers and the students. Providing meaningful input for students in language teaching is also drops off their anxiety level in producing English since it does not talk about the complicities of manipulation of grammatical construction. Language teaching that is taking a central point on forms, not meaning and all target language structures are being introduced and explained increase the students' anxiety and affect their fluency as well as their motivation [9]. Language learning that is not eliminating the main focus on forms is not promoting the students' meaningful input.

Due to the importance of providing meaningful input for acquisition in language teaching of higher education, the purpose of this study is to examine the effectiveness of the natural approach in language teaching in higher education.

\section{METHOD}

The study is quantitative research. The data in this study is in numbers and a statistical analysis used in it. This study is using an experimental approach. It has a pretest-posttest control group. The pretest given to both groups is to consider that they are at the same level of English proficiency. The test provided to the students is the test by using interview set to the students in higher education that are consisting of 72 students. A simple random sampling is used as a sampling technique to avoid the subjectivity of the researcher.

In collecting the data, the tests of English proficiency level by using interviews are used as the main data. Observations and documentation are used as the supporting data.

A t-test technique by a computer program SPSS version 19 for Windows is used to analyze the data. This study uses an independent t-test. Undertaking t-test, normality and homogeneity tests are undertaken.

\section{RESULTS AND DISCUSSION}

The data described in this study is the data of language learning between experimental groups, students receiving treatment of natural approach, and control groups, students getting treatment of conventional approach, without natural approach. Conducting pretest and posttest to experimental and control groups, this study has 4 (four) data those are the data of pretest of experimental and control groups in addition to the data of posttest of experimental and control groups.

\subsection{Pretest of Experimental Groups}

This research has data of pretest of experimental groups from the test by using interview before conducting treatment by using a natural approach. The participants of this study give responses in English to the test provided. The statistical descriptive results demonstrate that the mean is 49.25 , the median is 48.66, and the standard deviation is 9.53. The maximum score of the participants is 77.00; 34.00 is the minimum score for them. Table 1 describes the percentage criteria of pretest of experimental groups in higher education. 
Table 1. Percentage Criteria of Pretest of Experimental Groups

\begin{tabular}{|c|c|c|c|c|c|}
\hline & & Frequency & Percent & $\begin{array}{c}\text { Valid } \\
\text { Percent }\end{array}$ & $\begin{array}{c}\text { Cumulative } \\
\text { Percent }\end{array}$ \\
\hline \multirow[t]{4}{*}{ Valid } & $\begin{array}{l}\text { Able to meet routine social } \\
\text { conversation in a limited type of } \\
\text { profession. }\end{array}$ & 26 & 72.2 & 72.2 & 72.2 \\
\hline & $\begin{array}{l}\text { Able to participate in a conversation } \\
\text { with the accuracy of grammar and } \\
\text { vocabularies in formal and informal } \\
\text { situations associated with practical, } \\
\text { social, and professional matters. }\end{array}$ & 9 & 25.0 & 25.0 & 97.2 \\
\hline & $\begin{array}{l}\text { Able to participate to use the target } \\
\text { language fluently and accurately in all } \\
\text { levels of professional contexts in a } \\
\text { conversation with the accuracy of } \\
\text { grammar and vocabularies in formal } \\
\text { and informal situations associated with } \\
\text { practical, social, and professional } \\
\text { matters. }\end{array}$ & 1 & 2.8 & 2.8 & 100.0 \\
\hline & Total & 36 & 100.0 & 100.0 & \\
\hline
\end{tabular}

The output of the SPSS program of percentage criteria says that $26(72 \%)$ students are in level 2 (two) in English language proficiency level. It states that the students are being able to meet habitual community exchange in the incomplete type of profession. 9 (25\%) students are belonging to 3 (three) levels of English language proficiency. It affirms that they can join talk with the correctness of linguistics forms and vocabularies in ceremonial and unceremonious situations associated with practical, public, and professional areas, and 1 (3\%) students are in level 4 (four) of English language proficiency. It claims that students in higher education, the English Department of Madura University can utilize English confidently and precisely in all levels of professional situation.

\subsection{Pretest of Control Groups}

The data of the pretest of control groups is coming from the test provided to the participants of the study using interview when the teachers in higher education implemented conventional method, grammar-translation, before taking the action of treatment by using a natural approach. The participants of this study present answers in the target language. The statistical descriptive results reveal that the mean is 47.47 , the median is 46.75 , and the standard deviation is 7.50 . The maximum score of the participants is $64.00 ; 34.00$ is the minimum score of the subjects. Table 2 describes the percentage criteria of the pretest of control groups in higher education.

Table 2. Percentage Criteria of Pretest of Control Group

\begin{tabular}{llrrrr} 
& & Frequency & Percent & $\begin{array}{c}\text { Valid } \\
\text { Percent }\end{array}$ & $\begin{array}{c}\text { Cumulative } \\
\text { Percent }\end{array}$ \\
\hline Valid & $\begin{array}{l}\text { Able to meet routine social conversation in a } \\
\text { limited type of profession. }\end{array}$ & 28 & 77.8 & 77.8 & 77.8 \\
\hline
\end{tabular}


Able to participate in the conversation with the accuracy of grammar and vocabularies in formal and informal situations associated with practical, social, and professional matters.

Total

Table 2 shows the output of the SPSS program of percentage criteria displaying that $28(78 \%)$ students are in level 2 (two) in English language proficiency level. It states that the students are being able to assemble regular public conversation in the partial type of profession. $8(22 \%)$ students are apart of 3 (three) levels of English language proficiency. The students in higher education, the English Department of Madura University can speak English with the accuracy of linguistics forms and vocabularies in official and unceremonious situations coupled to a practical, public, and professional context. The results of the test to this group report that no students can able to use English fluently and accurately in all levels of professional context.$$
8
$$$$
22.2
$$

\subsection{Posttest of Experimental Groups}

The participants of this study are provided a natural approach in English language learning as the treatment. Then, they are offered the test of English proficiency level by using the interview. The results of the test area the data of the posttest. The posttest data of experimental groups is from the test by using interview after leading the students at higher education, the treatment by using the natural approach in English language learning. The descriptive statistic results show that the mean is 58.52, the median is 55.25 , and the standard deviation is 12.08. The maximum score of the participants is 82.00 , and 39.00 are the minimum score of them. Table 3 says the percentage criteria of posttest of experimental groups in higher education.

Table 3. Percentage Criteria of Posttest of Experimental Groups

\begin{tabular}{|c|c|c|c|c|c|}
\hline & & Frequency & Percent & $\begin{array}{l}\text { Valid } \\
\text { Percent }\end{array}$ & $\begin{array}{l}\text { Cumulative } \\
\text { Percent }\end{array}$ \\
\hline \multirow[t]{4}{*}{ Valid } & $\begin{array}{l}\text { Able to meet routine social conversation in a } \\
\text { limited type of profession. }\end{array}$ & 13 & 36.1 & 36.1 & 36.1 \\
\hline & $\begin{array}{l}\text { Able to participate in the conversation with the } \\
\text { accuracy of grammar and vocabularies in } \\
\text { formal and informal situations associated with } \\
\text { practical, social, and professional matters. }\end{array}$ & 15 & 41.7 & 41.7 & 77.8 \\
\hline & $\begin{array}{l}\text { Able to use the target language fluently and } \\
\text { accurately in all level of the professional } \\
\text { context }\end{array}$ & 8 & 22.2 & 22.2 & 100.0 \\
\hline & Total & 36 & 100.0 & 100.0 & \\
\hline
\end{tabular}

Table 3 affirms the output of the SPSS program of percentage criteria of the posttest of experimental groups after facilitating the treatment by using the natural approach in English language learning. It states that 13 (36.1\%) students are in level 2 (two) in English language proficiency level. It is showing that the students are being able to join habitual English conversation partially in the type of profession. $15(42 \%)$ students are belonging to 3 (three) levels of English language proficiency. It indicates that they can participate in the conversation in English with the accuracy of grammar and vocabularies in formal and informal situations coupled with practical, public, and professional areas, and $8(22.2 \%)$ students are in level 4 (four) of the English language proficiency. It says that students in higher education can utilize English smoothly and accurately in all levels of professional circumstances; they can put grammar in its place without interfering with communication.

\subsection{Posttest of Control Groups}

The subjects as control groups are given the test of English proficiency level at the end of the study. The data of the post-test of control groups is based on the score of the test. The statistical descriptive results tell that the mean of students in higher education is 52.16, the median is 49.33 , and the standard deviation is 10.06. The maximum score of the participants is $77.00 ; 39.00$ is the minimum score of the subjects. Table 4 tells the percentage criteria of posttest of control groups in higher education. 
Table 4. Percentage Criteria of Posttest of Control Group

\begin{tabular}{|c|c|c|c|c|c|}
\hline & & Frequency & Percent & $\begin{array}{l}\text { Valid } \\
\text { Percent }\end{array}$ & $\begin{array}{l}\text { Cumulative } \\
\text { Percent }\end{array}$ \\
\hline \multirow[t]{4}{*}{ Valid } & $\begin{array}{l}\text { Able to meet routine social conversation in a } \\
\text { limited type of profession. }\end{array}$ & 22 & 61.1 & 61.1 & 61.1 \\
\hline & $\begin{array}{l}\text { Able to participate in the conversation with } \\
\text { the accuracy of grammar and vocabularies in } \\
\text { formal and informal situations associated } \\
\text { with practical, social, and professional } \\
\text { matters. }\end{array}$ & 13 & 36.1 & 36.1 & 97.2 \\
\hline & $\begin{array}{l}\text { Able to use the target language fluently and } \\
\text { accurately in all level of the professional } \\
\text { context }\end{array}$ & 1 & 2.8 & 2.8 & 100.0 \\
\hline & Total & 36 & 100.0 & 100.0 & \\
\hline
\end{tabular}

Table 4 shows the output of the SPSS program of percentage criteria displaying that $22(61.1 \%)$ students are in level 2 (two) in English language proficiency level. It performs that the students are being able to bring together ordinary public dialogue in the partial type of profession. $13(36.1 \%)$ students are apart of 3 (three) level of English language proficiency. The students in higher education can converse English with the precision of grammar and vocabularies in an official and casual situation tied to a practical, public, and professional context. $1(2.8 \%)$ students are in level 4 (four) of English language proficiency. It says that students in higher education can use English efficiently and correctly in all levels of professional state of affairs.

The test of normality used is to know whether the data in the normal distribution. It tells that the distribution of the sample is normal if the test is non-significant $(\mathrm{P}>.05)$ but if the test insignificant $(\mathrm{P}<.05)$ it indicates that the distribution of the sample is non-normal. Table 5 indicates the result of the normality test of this study.

Table 5. The Result of Normality Test

\begin{tabular}{llrrrr} 
& & $\begin{array}{c}\text { Pre-test } \\
\text { control group }\end{array}$ & $\begin{array}{c}\text { Pre-test } \\
\text { experiment } \\
\text { group }\end{array}$ & $\begin{array}{c}\text { Post-test } \\
\text { control group }\end{array}$ & $\begin{array}{c}\text { Post-test } \\
\text { experiment } \\
\text { group }\end{array}$ \\
\hline Normal Parameters & a & 36 & 36 & 36 & 36 \\
& Mean & 47.4722 & 49.2500 & 52.1667 & 58.5278 \\
& Std. & 7.50042 & 9.53902 & 10.06692 & 12.08420 \\
& Deviation & .086 & .153 & .196 & .161 \\
Most Extreme Differences & Absolute & .086 & .153 & .196 & .161 \\
& Positive & -.066 & -.064 & -.095 & -.085 \\
Kolmogorov-Smirnov Z & Negative & .516 & .916 & 1.178 & .968 \\
Asymp. Sig. (2-tailed) & & .953 & .371 & .125 & .305 \\
\hline
\end{tabular}

The homogeneity test determines if two groups of populations have the same distribution of a single categorical variable. It is equal if the $(\mathrm{P}>$. 05), but it is not homogeny if $(\mathrm{P}<.05)$. Table 6 tells the test of homogeneity of variance.

Table 6. Test of Homogeneity of Variance

\begin{tabular}{|c|c|c|c|c|c|c|c|c|c|}
\hline \multicolumn{6}{|c|}{ Pre test } & \multicolumn{4}{|c|}{ Post test } \\
\hline & & $\begin{array}{l}\text { Levene } \\
\text { Statistic }\end{array}$ & df1 & df2 & Sig. & $\begin{array}{l}\text { Levene } \\
\text { Statistic }\end{array}$ & df1 1 & df2 & Sig. \\
\hline English & Based on Mean & .860 & 1 & 70 & .357 & 1.465 & 1 & 70 & .230 \\
\hline Proficiency & Based on Median & .849 & 1 & 70 & .360 & .958 & 1 & 70 & .331 \\
\hline
\end{tabular}




\begin{tabular}{lrrrrrrrr} 
Based on Median and & .849 & 1 & 64.655 & .360 & .958 & 1 & 68.327 & .331 \\
with adjusted df & .846 & 1 & 70 & .361 & 1.492 & 1 & 70 & .226 \\
\hline
\end{tabular}

There is a positive and significant difference in English language learning between the two groups of this study. Table 7 presents the output of the t-test of the hypothesis

Table 7. Independent Samples Test

\begin{tabular}{|c|c|c|c|c|c|c|c|c|c|c|}
\hline & & \multicolumn{3}{|c|}{$\begin{array}{l}\text { Levene's Test } \\
\text { for Equality of } \\
\text { Variances } \\
\end{array}$} & \multicolumn{4}{|c|}{ t-test for Equality of Means } & \multirow{2}{*}{\multicolumn{2}{|c|}{$\begin{array}{l}95 \% \text { Confidence } \\
\text { Interval of the } \\
\text { Difference }\end{array}$}} \\
\hline & & \multirow[t]{2}{*}{ F } & \multirow[t]{2}{*}{ Sig. } & \multirow[t]{2}{*}{ t } & \multirow[t]{2}{*}{ df } & \multirow[t]{2}{*}{$\begin{array}{l}\text { Sig. (2- } \\
\text { tailed) }\end{array}$} & \multirow[t]{2}{*}{$\begin{array}{c}\text { Mean } \\
\text { Difference }\end{array}$} & \multirow[t]{2}{*}{$\begin{array}{l}\text { Std. Error } \\
\text { Difference }\end{array}$} & & \\
\hline & & & & & & & & & Lower & Upper \\
\hline \multirow[t]{2}{*}{ Score } & $\begin{array}{l}\text { Equal } \\
\text { variances } \\
\text { assumed }\end{array}$ & 1.465 & .230 & -2.427 & 70 & .018 & -6.36111 & 2.62134 & -11.58920 & -1.13302 \\
\hline & $\begin{array}{l}\text { Equal } \\
\text { variances } \\
\text { not } \\
\text { assumed }\end{array}$ & & & -2.427 & 67.788 & .018 & -6.36111 & 2.62134 & -11.59220 & -1.13002 \\
\hline
\end{tabular}

Table 7 indicates that sig. (p) is significant. So, it can be concluded that students at higher education with a natural approach have better English proficiency level than those who are not. Moreover, the increase of mean score between pretest and posttest indicate the effectiveness of the natural approach in English language learning. Table 8 as follow point out the difference of mean between the two groups. The rise in the amount of mean between pretest and posttest of experiment group is 9.28, and 4.69 is the increase of mean between pretest and posttest of the control group. Therefore, the difference can be considered true.

Table 8. Group Statistics

\begin{tabular}{llrrrr} 
& Group & N & Mean & Std. Deviation & Std. Error Mean \\
\hline Score & Pretest Control group & 36 & 47.4722 & 7.50042 & 1.58984 \\
& Pretest Experiment group & 36 & 49.2500 & 9.53902 & 2.01403 \\
& Posttest Control group & 36 & 52.1667 & 10.06692 & 1.67782 \\
& Posttest Experiment group & 36 & 58.5278 & 12.08420 & 2.01403 \\
\hline
\end{tabular}

\section{DISCUSSION}

The purpose of this study is to describe the effectiveness of the natural approach in language learning in higher education. It conducts a pretest before implementing a natural approach in language learning. Statistical descriptive analysis of pretest shows that most of the students can meet habitual community exchange in the incomplete type of profession. Their English proficiency levels are in level 2. Experimental groups descriptive statistics show that the mean is 49.25 , the maximum score of the participants is 77.00; 34.00 are the minimum score, and the statistical descriptive results of control groups describe that the mean is 47.47 . The maximum score of the participants is $64.00 ; 34.00$ is the minimum score of the subjects.

However, after implementing a natural approach in language learning at higher education, statistical descriptive analysis of experimental groups in posttest indicates that students are belonging to 3 (three) levels of English language proficiency. They can take part in exchange in English with the accuracy of grammar and vocabularies in formal and informal situations coupled with practical, public, and professional areas. The mean is 58.52. The maximum score of the participants is 82.00 , and 39.00 is the minimum score. Nevertheless, descriptive statistics of control groups in the posttest show that students are 
unmoving. Their English language proficiency level is still in level 2 (two). They are not able to contribute dialogue with the accuracy of grammar and vocabularies in formal and informal situations connected to practical, social, and professional matters.

The principles of the natural approach are (1) comprehension precedes production. The language instruction is to help the students understand what is being said to them. Therefore, the teachers should always use English as the target language, the focus of communication will be on the topic of interest for the students, and the teachers will strive at all times to help students understand; (2) the production is allowed in stages. The stages consist of: a) response by nonverbal communication, b) response with a single word: yes, no, there, O.K., you, me, run, come, etc,; (c) combination of two or three words: paper on the table, me no go, where the book, don't go, etc., (d) phrases: I want to say, the boy running, etc., (e) sentences, and (f) more complex discourse. The students are forced to speak English before they are ready and speech errors that do not interfere with communication are not corrected; (3) syllabus consists of communicative goals, the classroom activities are organized by topics, not grammatical structure; (4) classroom activities are done for acquisition, a lowering of the affective filter of the students.

The natural approach offers some advantages to the success of the students in higher education in language learning. The natural approach helps the students to have the motivation and to cry off their anxiety in language learning as stated by [10] in his study for trends and issues in ELT methods and methodology mentions that the focus of language learning is to communicate their ideas, opinion, concepts, etc with English. The students have time to explore what they are thinking to deliver messages and meaning to their friends and their teachers. The important one in the language is the listeners or addresses can understand the messages in the target language. It is difficult for the students to produce their ideas and belief when they have high anxiety levels [11]. It is also a problem for their friends and teachers to comprehend what they are talking about. Therefore, the teachers are being supposed to formulate the teachinglearning process activities that can stimulate the students to communicate in English with no high hesitation and provide them with meaningful input [12] and [13].

The natural approach provided by the teachers in higher education is effective to make available meaningful input for the students. It is supported by [14] in his study about the natural approach of teaching the English language on a flipped classroom platform and by [15] in their research discussing the effect of methodology on learning vocabulary and communication skills in Iranian young learners: a comparison between audio-lingual method and natural approach that the students in higher education have a motivation to communicate in English since natural approach offers them low anxiety level. They can have responses in their L1 to the teachers' questions, explanations, invitation, command, etc. It gives them time to have interaction in English when they are ready. Moreover, the natural approach works out the poor acquisition.

The natural approach also offers students with fun activities and a good atmosphere in language teaching. The students with a natural approach naturally learn the language. This statement is relevant to [16] stating that the students are inspired to be in touch in English without a high worry level. It gives less stress on the teacher talking for a long time, making students repeat what the teachers say, and limiting the questions to the textbook alone, and more importantly, less focus on accuracy in terms of target language sentences [17]. In the natural approach, the teachers in higher education use English to converse in the classroom while the students can use either English or Madurese and Indonesian. The teachers are multi-faceted, ranging, from that of input provider to material constructor to activities supervisor [18] and [19]. The effectiveness of the natural approach in higher education is also supported by [20] asserting that the main role of the teachers is reducing and alleviating feelings of stress, tension, and anxiety to provide students with a comfortable situation in English language learning

In the natural approach, the teachers do not provide errors correction during communication and are not correct them by stopping the students' violence try. Manipulation of linguistic forms such as errors' correction, structure, and grammar give to the students outside the classroom as homework. They are discussing linguistic forms in an isolation activity [21]. It is also supported by [22] in her study on emotions in foreign language learning and use stating that it does not disturb the run of communication. The focus of the natural approach is comprehensible and meaningful input practice activities rather than the production of grammatical perfect utterances. [23] in his study about a critical review of Krashen's input hypothesis: three major arguments arguing that this kind of situation is boosting the students' motivation to 
communicate in English as well as providing a comfortable environment for the students. The teachers of higher education design the class based on the needs of the students. The students' needs are the focus of the teachers to facilitate them in English language learning [24]. The students involve single individuals, pairs, small groups, or the class as a whole in classroom activities to have interaction in English [25].

It can be implied that this study offers a solution to the obstacles and give some contribution to provide effective language learning in particular in higher education since the natural approach gives free form worry about English; it is connected to [26] natural approach builds teacher-student closeness since the students have more time to interact more in English to their teachers because of their hesitant is coming low. The language environment provided by the natural approach can enthuse and carry out fun activities. It is also supported by [27] claiming that the natural approach provides students meaningful input helping them to deliver meaning and have fluency in English. A natural approach can reduce the anxiety and worries of the students to use English in the interaction due to the students are possible to use both English and mother tongue as well as This kind of approach does not force the students to use English when the students are no ready [28]. When the teachers of higher education can reduce the worry and hesitation of the students in language learning, they are more open to input; this is facilitating success in language learning. The students with low anxiety levels have more possibility to have better English proficiency level in English. Students should not only be receptive to input in language learning but be in the position to use the language to have interaction confidently with others in English. The students believe that communication in English with their friend and their teachers is not difficult. It has to do with the advantages of the natural approach.

\section{CONCLUSION}

Based on the results and explanation of the research, it can be concluded that sig. (p) is significant; therefore, the difference between the two groups considered true, there is significance in language learning in higher education between students who have been given a natural approach and students who have experienced conventional methods. Language learning using a natural approach is more effective than language learning with the conventional method. The natural approach gives students opportunities to demonstrate their English with no hesitation. Also, it invites students to experience conversation in English naturally without considering mistakes of linguistics forms. Moreover, the natural approach increases the students' enthusiasm in English language learning since it provides students with comfortable activities as well as it is decreasing their anxiety level in expressing their ideas, opinions, and views in English as the students can give responses both in L1 tongue and English as their target language.

It implies that the teachers and members of academic society in higher education should assist students with the proper approaches to serve students with meaningful input, also, to provide students with interaction to the frequency of experiencing English; moreover, it is recommended that the members of academic society are being open to present meaningful input for the students and give natural communication regularly to the students.

\section{AUTHORS' CONTRIBUTIONS}

The authors confirm contribution to the paper as follows: Author 1: study conception and design data collection, analysis and interpretation of results; Author 2: draft manuscript preparation. All authors reviewed the results and approved the final version of the manuscript.

\section{ACKNOWLEDGMENT}

We show gratitude to Madura University that contributed and provided insight and expertise that greatly assisted the research.

\section{REFERENCES}

[1] C. chih Huang, "Other-repetition in Mandarin child language: A discoursepragmatic perspective," J. Pragmat., vol. 42, no. 3, pp. 825-839, 2010, doi: 10.1016/j.pragma.2009.08.005.

M. Swan, "Legislation by hypothesis: The case of task-based instruction," Appl. Linguist., vol. 26, no. 3, pp. 376401, 2005, doi: 10.1093/applin/ami013.

[3] U. R. Jannah, T. Nusantara, Sudirman, Sisworo, F. E. Yulianto, and M. Amiruddin, "Student's learning obstacles on mathematical understanding of a function: A case study in Indonesia higher education," TEM J., vol. 8, no. 4, pp. 1409-1417, 2019, doi: 10.18421/TEM84-44.

[4] N. Aksu, "Learning Languages without Grammar,” J. Educ. Soc. Res., vol. 4, no. $2,2014$. 
M. Goudarzi A., Parham, M. \& Jafar Mahdian, "The Influence of Natural Approach in Learning Language Skills (English) onBorujerd University Faculty Members," J. Basic Appl. Sci. Res., vol. 2, no. 9, pp. 9432-9437, 2012.

[6] T. Bahrani, "Importance of Language Input in Language Learning," Int. Res. J. Appl. Basic Sci., vol. 6, no. 10, pp. 1376-1379, 2013.

[7] J.-M. Dewaele and P. D. MacIntyre, "The two faces of Janus? Anxiety and enjoyment in the foreign language classroom," Stud. Second Lang. Learn. Teach., vol. 4, no. 2, pp. 237-274, 2014, doi: 10.14746/ssllt.2014.4.2.5.

[8] P. Indriawati, "JPE ( Jurnal Pendidikan Edutama ) Vol . 5 No . 2 Juli 2018," vol. 5, no. 2, pp. 1-9, 2018.

[9] M. Grossetti, "Powered by TCPDF (www.tcpdf.org) 1 / 1," How Lang. are Learn., vol. 12, pp. 27-40, 2013.

[10] A. Waters, "Trends and issues in ELT methods and methodology," ELT J., vol. 66, no. 4, pp. 440-449, 2012, doi: 10.1093/elt/ccs038.

[11] Ş. Yalçln and N. Spada, "Language aptitude and grammatical difficulty," Stud. Second Lang. Acquis., vol. 38, no. 2, pp. 239-263, 2016, doi: $10.1017 / \mathrm{S} 0272263115000509$.

[12] B. Boucher, E. Robertson, R. Wainner, and B. Sanders, "'Flipping' Texas State University's Physical Therapist Musculoskeletal Curriculum: Implementation of a Hybrid Learning Model," J. Phys. Ther. Educ., vol. 27, no. 3, pp. 72-77, 2013, doi: 10.1097/00001416-201307000-00010.

[13] R. Darvin and B. Norton, "Identity and a model of investment in applied linguistics," Annu. Rev. Appl. Linguist., vol. 35, no. 2015, pp. 36-56, 2015, doi: $10.1017 /$ S0267190514000191.

[14] D. P. Sam, "Natural Approach of Teaching English Language on a Flipped Classroom Platform to Tertiary Level Engineering Learners," Int. J. Educ. Sci., vol. 14, no. 1-2, pp. 13-18, 2016, doi: 10.1080/09751122.2016.11890474.

[15] A. R. Tehrani, H. Barati, and M. Youhanaee, "The effect of methodology on learning vocabulary and communication skills in Iranian young learners: A comparison between audiolingual method and natural approach," Theory Pract. Lang. Stud., vol. 3, no. 6, pp. 968-976, 2013, doi: 10.4304/tpls.3.6.968-976.
[16] Z. Dörnyei and L. Chan, "Motivation and vision: An analysis of future L2 self images, sensory styles, and imagery capacity across two target languages," Lang. Learn., vol. 63, no. 3, pp. 437462, 2013, doi: 10.1111/lang.12005.

[17] B. Vanpatten and M. Smith, "Aptitude as grammatical sensitivity and the initial stages of learning Japanese as AL2," Stud. Second Lang. Acquis., vol. 37, no. 1, pp. 135-165, 2015, doi: $10.1017 / \mathrm{S} 0272263114000345$.

[18] F. Vieira, "Task-Based Instruction for Autonomy: Connections With Contexts of Practice, Conceptions of Teaching, and Professional Development Strategies," TESOL Q., vol. 51, no. 3, pp. 693-715, 2017, doi: 10.1002/tesq.384.

[19] W. Westera, "On the changing nature of learning context: Anticipating the virtual extensions of the world," Educ. Technol. Soc., vol. 14, no. 2, pp. 201212, 2011.

[20] M. Amiruddin, "The role of social distance between teachers and students in English proficiency at MTsN Model Sumber Bungur Pakong."

[21] T. Gregersen, P. D. Macintyre, and M. D. Meza, "The Motion of Emotion: Idiodynamic Case Studies of Learners' Foreign Language Anxiety," Mod. Lang. J., vol. 98, no. 2, pp. 574-588, 2014, doi: 10.1111/j.15404781.2014.12084.x.

[22] Z. Robertson, "JALT Publications • Online Journals The Language Teacher," no. July, 2016.

[23] D. Liu, “A Critical Review of Krashen's Input Hypothesis: Three Major Arguments," J. Educ. Hum. Dev., vol. 4, no. 4, pp. 139-146, 2015, doi: 10.15640/jehd.v4n4a16.

[24] A. Bruton, "From tasking purposes to purposing tasks," ELT J., vol. 56, no. 3, pp. 280-288, 2002, doi: 10.1093/elt/56.3.280.

[25] S. Ahmad and C. Rao, "Applying communicative approach in teaching english as a foreign language: A case study of Pakistan," Porta Linguarum Rev. Int. didáctica las lenguas Extranj., no. 20, pp. 187-203, 2013.

[26] M. Amiruddin and U. R. Jannah, "PERAN LINGKUNGAN BAHASA DALAM PEMEROLEHAN BAHASA INGGRIS LISAN SANTRI DI PONDOK PESANTREN NURUL JADID PAITON," JPE ( J. Pendidik. Edutama), vol. 6, no. 1, pp. 65-76, 
2019.

[27] B. Skinner and M. C. Madden, "Help seeking in English language learning," ELT J., vol. 64, no. 1, pp. 21-31, 2009, doi: $10.1093 /$ elt/ccp019.

[28] W. YANG, "An investigation of learning efficacy, management difficulties and improvements in tertiary
CLIL (Content and Language Integrated Learning) programmes in Taiwan: A survey of stakeholder perspectives," Lat. Am. J. Content Lang. Integr.

Learn., vol. 9, no. 1, pp. 64-109, 2016, doi: 10.5294/lacli1.2016.9.1.4. 